\title{
Formation of reproductive organs in an early- ripening soybean variety, depending on the daylight duration
}

\author{
Valentina Sinegovskaya*, and Anna Levina \\ Federal State Budget Scientific Institution Federal Research Center «All-Russian Scientific Research \\ Institute of Soybean», Blagoveshchensk, 675027, Russian Federation
}

\begin{abstract}
To study the reaction of an early-ripening soybean variety to the formation of plant reproductive organs under the influence of different length of daylight hours, studies of 2 sowing periods in a growing house with a new early-ripening variety Sentyabrinka of the FSBSI FRC VNII of Soybean were conducted. Artificial reduction of the daylight duration to 8 hours was established from the phase of the 3rd triple leaf with alternating day and night periods in each variant 7 times during the growing season. The control was plants whose growth and development took place in natural light conditions. According to the research results, it was found that the change in the daylight duration during the vegetation period had a significant impact on the duration of the phases of plant growth and development, the growing season as a whole. When sowing soybeans on May 28 with a natural daylight, the height of plants and their seed productivity were higher than those of plants with a shortened daylight. At this sowing period, the highest productivity was obtained from one plant $9.3 \mathrm{~g}$, which is $1.0 \mathrm{~g}$ more compared to soybean plants with a sowing period of June 3 . The growth of plants, the formation of reproductive organs and the seed productivity of the early-repining variety Sentyabrinka depended on the duration of daylight, which can be regulated by the sowing period.
\end{abstract}

\section{Introduction}

Soybean is a culture of short daylight hours. The constituent factors of the light regime are the intensity and duration of illumination, the ratio of light and dark periods in the daily cycle-photoperiodism, on which the onset of the plant flowering phase depends [1-3]. The period from the formation of primordial leaves to the appearance of the first triple leaf is the most sensitive to the daylight duration. If the daylight hours are artificially reduced to 810 hours by shading plants, it is possible to accelerate the beginning of soybean flowering by 12-18 days. There is quite a lot of data on the possibility of regulating the formation of reproductive organs by influencing plants with various photoperiods [4-6]. At the same time, the passage of other development phases will also be faster. Numerous studies have established that for the transition to the reproductive stage, soybean plants require a certain

* Corresponding author: valsin09@gmail.com 
ratio of lighting and darkness. Artificial reduction of the daylight duration has a great influence both on the duration of the vegetation period as a whole, and separately on the phases of flowering, bean formation and seed filling, plant height and their productivity [710]. The flow of photosynthetic processes depends on the intensity of illumination in soybeans, due to the degree of absorption of light quanta by the leaf surface. The slowing down of photosynthesis leads to disturbances in the formation of reproductive organs, especially during the filling of beans, which can cause their fall and underdevelopment of seeds in beans [11]. The fall of flowers, ovaries and underdevelopment (abortivity) of seeds are common in many crops, soybean is no exception in this case. It was found that from 40 to $80 \%$ of the flowers and ovaries fall off in soybeans, depending on the variety and growing conditions $[12,13]$. Therefore, it is very important to create a favorable level of illumination and the duration of daylight for the course of active photosynthesis. According to V.I. Sichkar, if unfavorable factors develop in the initial period of bean formation, then crop losses can be compensated for in the final phases of flowering and bean formation, if conditions improve at the same time [14]. In this regard, the purpose of our research was to study the formation of reproductive organs in a new early-ripening soybean variety Sentyabrinka, with an artificial reduction in the duration of daylight.

\section{Materials and methods}

In 2019-2020, experiments on the influence of the daylight duration on the formation of reproductive organs of the early-ripening soybean variety Sentyabrinka of the VNII of Soybean were conducted in the conditions of the vegetative house of the Laboratory of plant physiology of the FSBSI FRC VNII of Soybean. The variety belongs to the earlyripening group with a vegetation period of 87-99 days and a potential yield of $2.64 \mathrm{t} / \mathrm{ha}$, a protein content of at least $42.3 \%$ and fat of $19.2 \%$. The variety is characterized by an indeterminate type of growth with the number of branches from 1 to three pieces, is resistant to waterlogging of the soil and lodging, as well as to fungal and bacterial diseases of soybeans.

The plants were grown in Wagner vessels, the filling of the vessels was carried out with meadow chernozem soil according to the method of F.A. Yudin, [15] soil moisture and moisture capacity were determined by the method of Z.I. Zhurbitsky [16].

Before sowing, the seeds were treated with a solution of ammonium molybdate $(1 \mathrm{~g}$ per $100 \mathrm{ml}$ of water) and inoculated with nodule bacteria of the TB-467 strain, at the rate of 1 million cells per 1 seed. When sowing in 2020, we used seeds obtained in 2019 in an experiment where plants were grown with a reduction in daylight hours to 8 hours. Sowing was carried out on May 28 and June 3, five seeds per vessel, after germination 3 plants were left in the vessel, the repetition in the experiment was 4-fold. During the entire vegetation period, the soil moisture was maintained at the level of $80 \%$ FWC.

The closure of plants in vessels to change the daylight duration up to 8 hours was carried out from the phase of the fourth node, with the duration of the dark period of 16 hours. The alternation of the day and night periods in each variant was carried out 7 times during the vegetation period. The control in each sowing period was plants whose growth and development took place in natural light conditions. Records and observations of the formation of reproductive organs, depending on the photoperiods, were carried out according to the method of E. F. Lopatkina [17]. Phenological observations were carried out daily during the vegetation period from the germination phase to the full maturation of seeds, marking the growth and development phases according to the method of Fehr W. et al. [18] Accounting of the formation of reproductive organs from the beginning of flowering phase (R1) to the full ripeness phase (R8) was carried out according to the 
method of E.F. Lopatkina [19]. Determination of the crop structure, crop accounting according to the SSEUM method [20].

\section{Results and discussion}

Observations of the development of the 7early-ripening variety Sentyabrinka showed that the duration of the interphase periods and, in general, the entire vegetation period depended on the length of the daylight (Table 1). On average, for 2 years of research, under natural lighting conditions, the maximum vegetation period - 96 days, was observed in soybean plants when sown on May 28. In this case, the plants grew and developed in conditions of a longer daylight. The minimum vegetation period was 89 days for plants with sowing on June 03 , it decreased due to a decrease in the duration of the interphase period "the beginning of seed formation - full ripeness" due to a decrease in the duration of daylight compared to the sowing on May 28.

Table 1. The duration of the phenological periods of plant growth and development and the vegetation period of the early-ripening variety Sentyabrinka, depending on the sowing period and the daylight duration, days (average for 2019-2020).

\begin{tabular}{|c|c|c|c|c|c|c|c|}
\hline \multirow[b]{2}{*}{$\begin{array}{c}\text { Period of } \\
\text { sowing } \\
\text { (Factor } \\
\text { A) }\end{array}$} & \multirow[b]{2}{*}{$\begin{array}{l}\text { Daylight } \\
\text { length } \\
\text { (Factor B) }\end{array}$} & \multicolumn{5}{|c|}{ Period of plant growth and development } & \multirow[b]{2}{*}{ 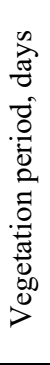 } \\
\hline & & $\begin{array}{l}\text { Shoots } \\
\text { 4th node }\end{array}$ & $\begin{array}{l}\text { 4th node - } \\
\text { beginning } \\
\text { of } \\
\text { flowering }\end{array}$ & $\begin{array}{c}\text { Beginnin } \\
\mathrm{g} \text { of } \\
\text { flowerin } \\
\mathrm{g}- \\
\text { beginnin } \\
\mathrm{g} \text { of the } \\
\text { bean } \\
\text { formatio } \\
\mathrm{n}\end{array}$ & $\begin{array}{l}\text { Beginning } \\
\text { of bean } \\
\text { formation - } \\
\text { beginning } \\
\text { of seed } \\
\text { formation }\end{array}$ & $\begin{array}{l}\text { Beginning } \\
\text { of seed } \\
\text { formation } \\
\text { - full } \\
\text { ripeness }\end{array}$ & \\
\hline \multirow[t]{2}{*}{28.05 . } & $\begin{array}{c}\text { Control - } \\
\text { natural } \\
\text { lighting }\end{array}$ & 29 & 3 & 14 & 12 & 38 & 96 \\
\hline & $\begin{array}{c}\text { 8-hour } \\
\text { daylight* }\end{array}$ & 30 & 1 & 11 & 11 & 36 & 88 \\
\hline \multirow[t]{2}{*}{3.06 . } & $\begin{array}{c}\text { Control - } \\
\text { natural } \\
\text { lighting }\end{array}$ & 26 & 7 & 14 & 13 & 29 & 89 \\
\hline & $\begin{array}{c}\text { 8-hour } \\
\text { daylight* }\end{array}$ & 35 & 4 & 11 & 14 & 24 & 88 \\
\hline
\end{tabular}

Note $-*$ from the fourth node phase

The artificial reduction of the daylight duration to 8 hours from the phase of the fourth node $\left(\mathrm{V}_{4}\right)$ led to a reduction of the vegetation period by 8 days for plants with a sowing on May 28 and by 1 day for sowing on June 03. The height of plants decreased by $9 \ldots 10 \mathrm{~cm}$ with a reduction in daylight hours, depending on the time of sowing soybeans, which led to a decrease in the number of beans and seeds on plants (Table 2). The average correlation between the duration of daylight and the height of plants, regardless of the sowing period, has been established. The correlation coefficient was 0.68 with sowing on May $28\left(\mathrm{~d}_{\mathrm{yx}}=\right.$ $0.46)$, and 0.62 with sowing on June $03\left(\mathrm{~d}_{\mathrm{yx}}=0.38\right)$. At the time of sowing on May 28, the number of beans per 1 plant decreased by 4 pcs., and the number of seeds - by 18 pcs. Plants with a sowing period of June 3 were formed for 1 bean, and seeds were 4 pieces less than those of the plants of the control variant. 
In conditions of natural light, the number of seeds per 1 plant was the highest in the variant with sowing on May 28; and with a sowing on June 03, this indicator decreased by $25.8 \%$, which indicates more favorable conditions for the degree of illumination and the duration of daylight during sowing on May 28.

Table 2. The influence of daylight hours on plant growth and their productivity of the early-ripening soybean variety Sentyabrinka, (average for 2019-2020).

\begin{tabular}{|c|c|c|c|c|}
\hline \multirow{2}{*}{$\begin{array}{c}\text { Sowing } \\
\text { period }\end{array}$} & Variant & $\begin{array}{c}\text { Plant height, } \\
\mathrm{cm}\end{array}$ & $\begin{array}{c}\text { Number of beans } \\
\text { from 1 plant, pcs. }\end{array}$ & $\begin{array}{c}\text { Number of seeds } \\
\text { from 1 plant, pcs. }\end{array}$ \\
\hline \multirow{2}{*}{ May 28 } & $\begin{array}{c}\text { Control - natural } \\
\text { lighting }\end{array}$ & 57 & 22 & 58 \\
\cline { 2 - 5 } & 8-hour daylight* & 47 & 18 & 40 \\
\hline \multirow{2}{*}{ June 3 } & $\begin{array}{c}\text { Control - natural } \\
\text { lighting }\end{array}$ & 52 & 19 & 43 \\
\cline { 2 - 5 } & 8-hour daylight* & 43 & 18 & 39 \\
\hline \multicolumn{2}{|c|}{ LSD 05 , on av. for the experiment } & 3,13 & 2,58 & 5,03 \\
\hline
\end{tabular}

Note $-*$ from the fourth node phase

An important factor that ensures high plant productivity is the set of beans and seeds, as well as their safety and seed filling capacity in beans. The greatest fall of the reproductive organs was noted among the flowers of the plants of the control variants with sowing on June 03 and amounted to $59.3 \%$ (Fig. 1). The number of fallen bean ovaries was also the highest at this time of sowing.

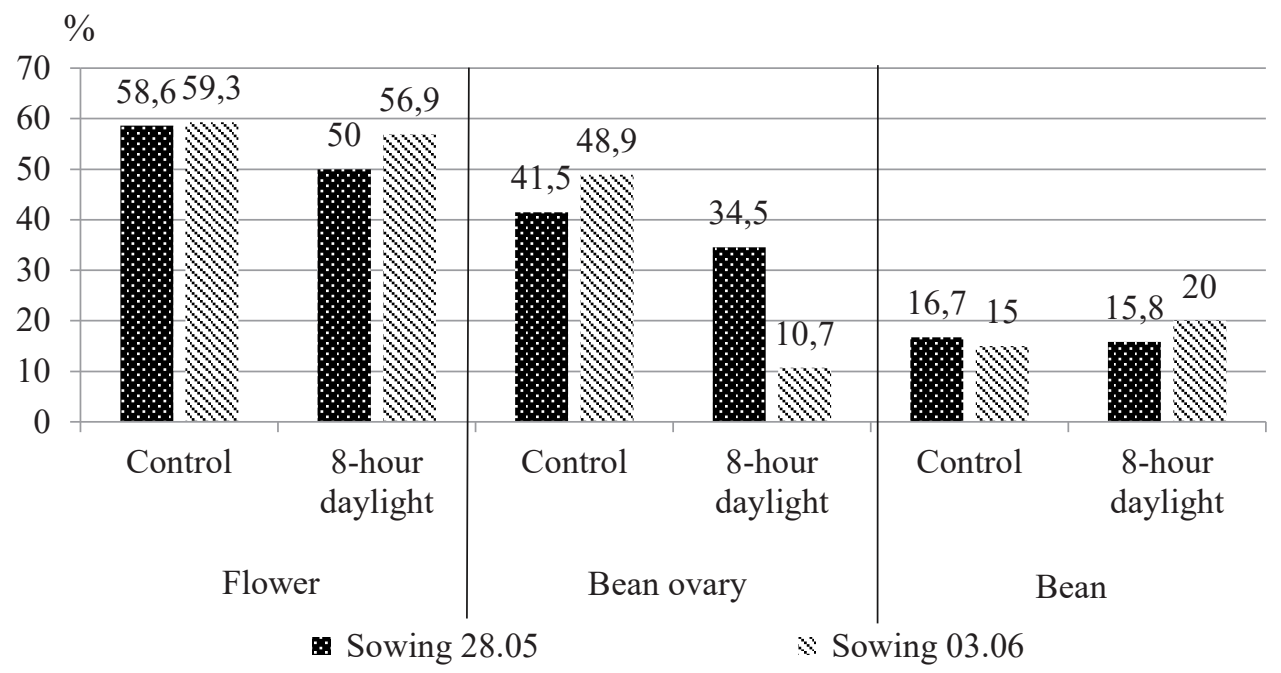

Fig. 1. The share of fallen reproductive organs in plants of the early-ripening soybean variety Sentyabrinka, depending on sowing period and daylight duration, \%, 2020.

Artificial reduction of daylight hours to 8 hours at the sowing time on 28.05 reduced the abortivity of flowers to $50 \%$, bean ovaries - to $34.5 \%$, and formed beans - to $15.8 \%$. The reduction of daylight hours to 8 hours had the least effect on the fall of the bean ovaries at the sowing on June 03 , reducing the fall of the ovaries to $10.7 \%$. 
The daylight duration, having an impact on the height of plants and the formation of reproductive organs, led to a decrease in the seed productivity of plants (Fig. 2). The weight of seeds from 1 plant was the highest in the variant with natural light at the sowing on May 28. When sowing on June 3, this indicator decreased by $10.6 \%$. Under the conditions of 8 hour daylight, the weight of seeds from 1 plant decreased by $1.6 \mathrm{~g}$ when sown on May 28, and by $1.4 \mathrm{~g}$ when sown on June $3\left(\mathrm{LSD}_{05}=0.9 \mathrm{~g}\right.$ ) relative to the control. Consequently, the reduction of daylight hours had a negative impact on the seed productivity of earlyripening soybean variety, regardless of the sowing period. The most favorable conditions for daylight duration were created in the version with natural light with sowing on May 28, which is confirmed by the data on the seed productivity of plants of the early-ripening soybean variety Sentyabrinka.

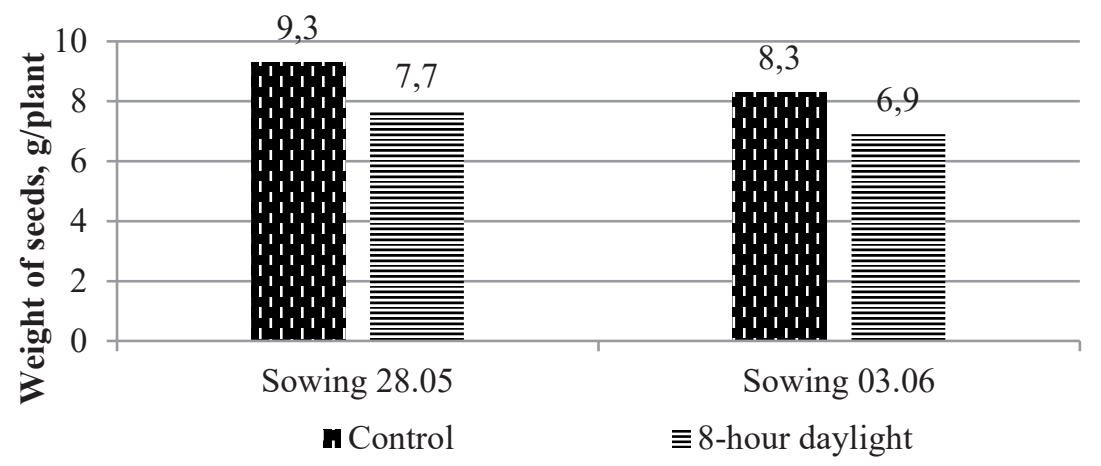

Fig. 2. Productivity of the early-ripening variety Sentyabrinka depending on the sowing period and the daylight duration, g/plant, (average for 2019-2020).

\section{Conclusions}

The growth of plants, the formation of reproductive organs and the seed productivity of the early-repining variety Sentyabrinka depended on the duration of daylight, which can be regulated by the sowing period. The artificial reduction of the daylight duration to 8 hours did not lead to an increase in plant productivity, since the indicators of plant height and the number of beans and seeds per 1 plant decreased, which led to a decrease in the weight of seeds from the plant. Theoretically, when calculated per 1 hectare, crop losses can reach up to $0.9 \mathrm{t} / \mathrm{ha}$. Our research confirms the data of V.B. Enken (1959) that the optimal daylight duration for soybeans is the duration of 12-13 hours, and a further decrease leads to a decrease in the growth, development and productivity of plants.

\section{References}

1. W.W. Garner, H.A. Allard, Photoperiod response of soybean in relation to temperature and other environmental factors, 41, 719-735 (1970)

2. M. Nico, D. Miralles, AG. Kantolic, Natural post-flowering photoperiod and photoperiod sensitivity: Roles in yield-determining processes in soybean 231, 141-152 (2019) DOI: https://doi.org/10.1016/j.fcr.2018.10.019

3. S.R. Zhang, H. Wang, Z.Y. Wang, Photoperiodism dynamics during the domestication and improvement of soybean, $\mathbf{6 0}$ (12), 1416-1427 (2017) DOI: https://doi.org/10.1007/s11427-016-9154-x 
4. S. Arabidzhiev, Soy, Kolos 197 (1981)

5. L.V. Nazarenko, Environmental factors, their influence on the growth and development of long-day agricultural crops on the example of wheat, 93(09), (2013)

6. V.S. Zelentsov, A.A. Saveliev, A.S. Luchinsky, T.V. Pasmenko, V.B. Luneva, Determination of the soy reaction to the length of the day by the degree of completion of vegetative plant growth, 1(140), 91-96 (2009)

7. A.P. Ustyuzhanin, A.V. Shevchenko et al. Selection of soybean varieties of the northern ecotype, 225 (2007)

8. G. Zhang, The Effects of Daylength on the Growth of Soybean and the Creation of Wide- adaptation Germplasm, 26 (1999)

9. G.H. Freiria, W.F. Lima, R.S. Leite, Productivity and chemical composition of foodtype soybeans sown on different dates, 38 (3), 371-377 (2016) DOI: https://doi.org/10.4025/actasciagron.v38i3.28632

10. E.V. Mysak, O.A. Selikhova, P.V. Tikhonchuk, The influence of the photoperiod on the sowing qualities of seeds and the main elements of soybean productivity, $6,51-53$ (2014)

11. E.F. Lopatkina, Dependence of abortivity of soybean seeds on growing conditions, 105-108 (1983)

12. A.I. Gromova, Abortivity of seeds in soybeans, 2, 66-70 (1968)

13. V.V. Ochkurova, Study of the processes of abortivity of flowers, beans and soybean seeds depending on growing conditions, 85-86 (2019)

14. V.I. Sichkar, Results of soybean breeding in the Breeding and Genetic Institute of the $U A A S$, 54-68 (1997)

15. F.A. Yudin, Methods of agrochemical research, 366 (1980)

16. Z.I. Zhurbitsky, Theory and practice of the vegetative method, 260 (1968)

17. E.F. Lopatkina, Photoregulation of the duration of the stages of soybean organogenesis in connection with the tasks of breeding, 126-129 (1987)

18. W.R. Fehr, C.E. Caviness, D.T.Burmood, J.S.Pennington, Stages of development descriptions for soybeans, 11, 929-930 (1971)

19. E.F. Lopatkina, Methodology of quantitative accounting of soy reproductive organs, 7 (8), 34-42 (1977)

20. Methodology of the state variety testing of agricultural crops, 195 (1989)

21. V.B. Enken, Soy, 321 (1959) 